\title{
Exploring the Relationship between Customer Equity and Satisfaction: An Empirical Study of Mongolian Gas Station Channels
}

\author{
Tain-Fung $\mathrm{Wu}^{1}$ and Munkh-Ulzii Batmunkh ${ }^{1+}$
}

\begin{abstract}
To survive in the highly competitive markets, many firms strive to make fundamental changes and differentiate itself from competitors in the industry. The firms success depend on customer perception toward the products and services of a company. This study aims to explore relationships between customer equity, which represents value equity, brand equity, relationship equity, and to customer satisfaction. We present the results of our research work conducted through marketing channels of the Petrovis Limited Liability Company, a petroleum company of Mongolia, as the case firm in this study. The findings show customer equity leads to satisfaction.
\end{abstract}

Index Terms-Customer Equity, Customer Satisfaction, Customer Relationship Management, Value Equity, Brand Equity, Relationship Equity.

\section{INTRODUCTION}

Most studies of customer equity and channel marketing theories started from the Western world rather than from Asian countries. Since the second half of the twentieth Century, bi-polar political systems had dominated the world as capitalist and communist that adopted centralised economic systems.

Perceiving what a customer wants is more difficult than listening to a customer. However, it is more difficult to establish the database of a consumer's lifelong purchase by conducting a monthly customer behaviour survey. In order to understand the consumer requirements, a firm has to find the factors that motivate the customer to start a transaction with the firm, and proceed doing business with that firm in the future. According to the theory, customer equity is defined as: "the sum of the discounted lifetime values of all of its consumers." Therefore, acting more in a relevant way in response to customers based upon understanding about customers to cultivate their loyalty.

After being a communist country for seventy years, there has been only twenty years since Mongolia stepped into market oriented economy. Comparing with other countries that have passed many decades, there still need to survive the Mongolian market as seen from capitalist standards.

Consequently, the author is very fascinated to do research

\footnotetext{
${ }^{1}$ Department of Business Administration, College of Management, Asia University, 500, Lioufeng Rd., Wufeng, Taichung, Taiwan, R.O.C.

+Corresponding author. Tel.:+886-0928494724;

+886-4-23316699 e-mail address: ulzii03@gmail.com
}

in this field. The researcher conducted this study to find out how customer equity model impact on loyalty in the Mongolian market. Thus, regarding the framework of marketing channels and market share, the research work conducted through distribution channels of Petrovis Limited Liability Company (LLC), the largest petroleum company in Mongolia,which has been operating as a importer and retailer of oil products, in Ulaanbaatar. According to the statistics, 161,989 vehicles had been operating in Mongolia, and 92,706 vehicles in Ulaanbaatar by 2008 .

Thus, research had been more centralised in Ulaanbaatar.

Research Objectives. The study has the following research questions, which appears as the main base of research objectives, to reveal how customer satisfaction has been established, and in what the customers to be satisfied: (1) What is the relationship between value equity and satisfaction? (2) What is the relationship between brand equity and satisfaction?, and (3) What is the relationship between relationship equity and satisfaction?

\section{Study Design}

1) Methodology Framework

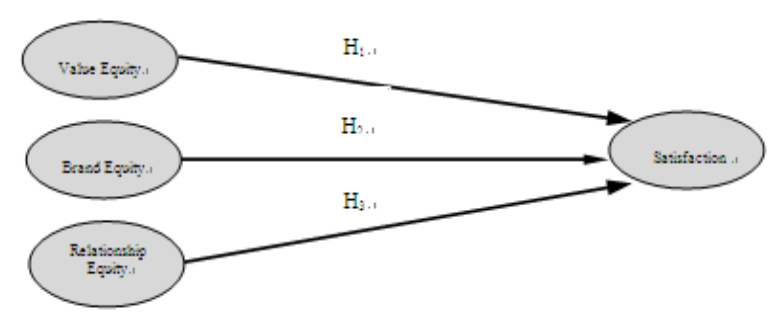

Figure 1. Methodology Framework

2) Research Variable Measurement and Hypothesis Development

The items for measuring the constructs of the research had been developed, drawing on prior scientific papers and literatures. The initial items and constructs were tested by fifty five managers of the case company, and a pre-test within 60 customers. The procedure led to the final survey instrument for the research. The five-point categorical Likert scales (Strongly agree, Agree, Uncertain, Disagree, Strongly disagree) employed to measure each construct of both stages. Related to the conceptual model, shown in the Figure 1, the following four constructs were of primary interest: Value equity, Brand equity, Relationship equity, and Satisfaction. 
The research variables and measurements are stated as the following:

Value equity. According to the researchers` findings, value equity is the consumers' objective assessment of the usage of a brand based on understanding of things that is given up for what is received. Brand equity is more subjective and emotional. It has a tight connection with the intangible assessment of a brand, above and beyond its objectively perceived value (Luo et al, 2008). Value equity, the first driver of loyalty, can be understood as the perceived ratio between what is received and what has to be sacrificed. Value equity is consisted of the following three drivers: quality, price, convenience. Furthermore, researchers pointed out that value equity has an impact on a customer's switching propensity, a measure similar to satisfaction and loyalty intentions (Lemon et al, 2000). In our study it is hypothesized that,

$\mathrm{H}_{1}$ : Perceived value equity has a positive impact to customer satisfaction.

Brand Equity. According to literature (Kevin Lane Keller et al, 2000), brand equity is the subjective estimation of a customer's choice. Brand equity is defined as a financial assessment of the value of a brand identity that a customer is willing to pay price premium to a certain brand identity versus others. A strong brand can be an umbrella under which to launch new products existing ones, a resiliency to survive crisis situations, and protection from competitive attack periods of lack of corporate support or shifts in consumer tastes (Pao-Long et al, 2006). Rust (2000) states that brand equity is hopefully to influence customer willingness staying, considering repurchases, or to recommend the brand. Brand equity is consisted of the following drivers: (1) customer brand awareness, (2) customer attitude toward the brand, and (3) customer perception of brand ethics. Our study hypotheses that,

$\mathrm{H}_{2}$ : Perceived brand equity has a positive impact to customer satisfaction.

Relationship Equity. According to Monle Lee (2005), relationship equity is a customer's tendency to stick with the brand, above and beyond objective and subjective assessment of the brand. It resulted from the elements that link a customer to a brand or a company. If the perceived relationship equity is high, the consumers will be satisfied and it would lead to repurchase (Rust et al, 2001). If the perceived relationship equity is high, the consumers will feel well treated and handled with special care (Kristof et al, 2001). Relationship equity results from the following drivers: (1) Loyalty, (2) Special Recognition and Treatment Programs, (3) Affinity/Community Programs, (4) Knowledge Building Programs. Our study hypotheses that,

$\mathrm{H}_{3}$ : Perceived relationship equity has a positive impact on customer satisfaction.

Satisfaction. The topic of 'customer satisfaction' has held a significant position in the marketing literature over from decades since satisfied customers can generate long-term benefits for companies, including customer loyalty and sustained profitability. Researchers (Luo et al, 2007) have explained the mechanism of customer satisfaction with a number of distinct theories, such as expectancy-disconfirmation theory, contrast theory, assimilation or cognitive dissonance theory, equity theory, and value-percept theory. Among them, the most widely accepted theory is the expectancy disconfirmation theory. In this context, marketing literature consistently identifies customer satisfaction as a key antecedent to loyalty and repurchase (Drago et al, 2001).

Method. Descriptive statistics, regression analysis, and reliability analysis are utilized in our study.

Sample. The study was conducted in two stages of pretesting and real survey. The survey questionnaire was subsequently pre-tested by 55 managers as well as 60 customers of the case company. Their feedbacks were used to modify the questionnaire before the real investigation. In this study, 146 respondents from the customers of gasoline industry of Mongolia were involved. The data collection for this study was done by using quota sampling techniques.

\section{DATA ANALYSIS}

Based on process assessment, the author used the following steps to run the operations. The author distributed 146 copies of the questionaire, to the public, each consisting of 14 questions. We collected received 146 valid responses.

Reliability analysis. In this study reliability is constructed by Construct reliability, (CR) and variance extraction (VE). The author tried to construct the reliability model and examine the reliability of the variables. According to Fornell \& Larcker (1981), the dimensions of the internal CR and VE are acknowledgeable if the internal consistency threshold is above .7. CR value is the examined model which used to observe all of the variables and measure the reliability from all of those indicators. The proposed value was raised by (Fornell \& Larcker, 1981). (Jöreskog and Sörbom 1989) provides the calculation of CR-type for the $\mathrm{CR}=(\Sigma$ standardized factor loading $) 2 /((\Sigma$ standardized load factor $) 2$ $+(\Sigma$ measurement variables of the measurement error $))$.

$\mathrm{VE}$ is the calculation of the potential variables from the measurement variables. The latent variables can explain the variation of those variables, and if the VE values are higher, the potential variables will have higher reliability and convergent validity. Jöreskog and Sörbom (1989) provide the research related to these calculations. The calculation of VE-type is: $\mathrm{VE}=\Sigma$ (load factor $)^{2} /\left(\left(\Sigma\right.\right.$ load factor $\left.{ }^{2}\right)+(\Sigma$ measurement variables of the measurement error)).

The study dimensions of variables are larger than the CR values of .7, indicates that the model of this study reached the level of dimensions.

TABLE 1. CONSTRUCTION OF MODEL RELIABILITY AND VARIANCE EXTRACTED AgGREGATE VOLUME TABLE

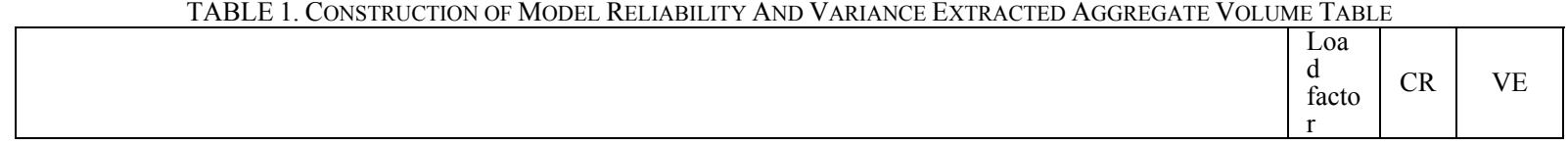




\begin{tabular}{|c|c|c|c|c|}
\hline \multicolumn{5}{|c|}{ PART A } \\
\hline \multicolumn{5}{|c|}{ Understand customer's perception towards value, price and convenience offered by the brand (the company) } \\
\hline \multirow{5}{*}{ Value } & A1. I prefer to buy gasoline from the company, which represents good quality & .716 & \multirow{5}{*}{.922} & \multirow{5}{*}{.704} \\
\hline & A2. I perceive the speedy service job offered by gas station workers & .908 & & \\
\hline & A3. I perceive the product quality of this brand channel as higher than other company's & .900 & & \\
\hline & A4. I perceive it as convenient that buying at the gas station close to my home or working place & .880 & & \\
\hline & A5. I prefer to buy gasoline from a gas station which has mini market facilities & .774 & & \\
\hline \multicolumn{5}{|c|}{ Understand customers` perception towards brand awareness, brand attitude, and brand ethics } \\
\hline \multirow{3}{*}{ Brand } & B1. This company is well known company in oil product industry & .608 & \multirow{3}{*}{.895} & \multirow{3}{*}{.748} \\
\hline & B2. By my experience I trust this company compared to others & .968 & & \\
\hline & B3. I know this company always campaign about environmental friendly & .968 & & \\
\hline \multicolumn{5}{|c|}{ Understand customers' perception towards the relationship with company (Brands) } \\
\hline \multirow{3}{*}{ Relationship } & C1. Company manages club activities & .961 & \multirow{3}{*}{.972} & \multirow{3}{*}{.919} \\
\hline & C2. Company will consult with me about how to make improvement & .957 & & \\
\hline & C3. I will be informed if new products are newly available & .958 & & \\
\hline \multicolumn{5}{|c|}{ Understand the degree of customers`satisfaction towards company's offerings } \\
\hline \multirow{3}{*}{ Satisfaction } & D1. I am highly satisfied with the value of offerings in product quality, service & .820 & \multirow{3}{*}{.905} & \multirow{3}{*}{.760} \\
\hline & D2. I am satisfied with the price of offerings & .915 & & \\
\hline & D3. I am satisfied with the convenience company renders & .878 & & \\
\hline
\end{tabular}

We can see from Table 1, the study dimensions are larger than .7 , indicating the model of this study was to observe the variables measuring the potential to reach the level of dimensions. Therefore, this study observed variables and latent variables are reliability to meet construction standards.

Demographic Data Analysis by ANOVA analysis. The demographic data of this study is divided into Gender, Age, Education, Number of children, Vehicle type, Cylinder capacity, Occupation, Annual income and Location. Gender aspects in order to female most customers, a total of 110 accounted for $75.3 \%$; in the Age, in terms of $40-49$ years most of the customers, a total of 55 accounted for $37.7 \%$; in Education, the high school in the majority of customers, a total of 66 accounted for $45.2 \%$; in the Number of children have, in order to most customers two children, a total of 66 accounted for $37.7 \%$; in the Vehicle type, in order to most customers sport, a total of 63 accounted for $43.2 \%$; in Cylinder capacity, in order to 40 litter most customers, a total of 36 people accounted for $24.7 \%$; in the Occupation, the customers most of the workers living in the industry, a total of 65 accounted for 44.5 percent; in the Annual income, the customers for the 2001-2500 USD and 2501-3000 USD, a total of 82 accounted for $57.6 \%$; in Location, the majority of customers for the central, a total of 55 accounted for $37.7 \%$. None of the dimensions, except value, reached a significant level.

\section{The Various Dimensions of the ANOVA}

\section{Gender}

Gender of the customer-Part A $\sim \mathrm{E}$ for T-test, the results shown in Table 2, such as, Brand, Relationship, Satisfaction are less than significant level, showing them in the face of no significant impact on Gender. The Value of a significant level, showing them in the face of Gender has a significant impact.

TABLE 2. GENDER DiMENSIONS OF ALL THE DifFERENCES BETWEEN

\begin{tabular}{cccc}
\hline & F value & P value & $\begin{array}{c}\text { Has reached a significant } \\
\text { level? }\end{array}$ \\
\hline Value & 6.889 & .010 & Yes \\
\hline Brand & 1.872 & .173 & No \\
\hline Relationship & 3.385 & .068 & No \\
\hline Satisfaction & 0.240 & .625 & No \\
\hline
\end{tabular}

Age

Age to customers on the Part A $\sim \mathrm{E}$ for T-test, the results shown in Table 3, such as, Value, Brand, Relationship,
Satisfaction did not reach significant level, showing them in the face of no significant impact of Age. 


\begin{tabular}{cccccccc}
\hline & $18-29$ years & $\begin{array}{c}30-39 \\
\text { years }\end{array}$ & $\begin{array}{c}40-49 \\
\text { years }\end{array}$ & $\begin{array}{c}50-59 \\
\text { years }\end{array}$ & F-value & P-value & Duncan \\
\hline Value & 4.06 & 4.21 & 3.97 & 4.14 & 1.016 & .388 & Not significant \\
\hline Brand & 4.07 & 4.01 & 3.85 & 3.94 & 0.470 & .703 & Not significant \\
\hline Relationship & 3.96 & 4.19 & 4.15 & 4.35 & 4.23 & .737 & Not significant \\
\hline Satisfaction & 4.03 & 4.01 & 3.81 & 4.04 & .682 & .564 & Not significant \\
\hline
\end{tabular}

Education

Education to customers on the Part $\mathrm{A} \sim \mathrm{E}$ for ANOVA analysis, the results as shown in Table 4, in addition to the standard of no significant Satisfaction.

TABLE 4. EDUCATION OF THE DIFFERENCES BETWEEN THE VARIOUS DIMENSIONS

\begin{tabular}{cccccccc}
\hline & $\begin{array}{c}\text { Below } \\
\text { High } \\
\text { school }\end{array}$ & $\begin{array}{c}\text { High } \\
\text { school }\end{array}$ & College & $\begin{array}{c}\text { Above } \\
\text { University }\end{array}$ & F-value & P-value & Duncan \\
\hline Value & 3.96 & 4.06 & 4.34 & 3.95 & 2.159 & .096 & Not significant \\
\hline Brand & 3.82 & 3.90 & 4.18 & 3.76 & 1.740 & .161 & Not significant \\
\hline Relationship & 4.00 & 4.23 & 4.39 & 3.91 & 1.229 & .302 & Not significant \\
\hline Satisfaction & 3.98 & 3.94 & 3.95 & 3.82 & .109 & .955 & Not significant \\
\hline
\end{tabular}

\section{Children}

indicating Children between the various dimensions have no

Children of the customer's Part A $\sim$ E for ANOVA analysis, significant effect. the results as shown in Table 5, did not reach significant level,

TABLE 5. CHILDREN OF THE DiFFERENCES BETWEEN THE VARIOUS DIMENSIONS

\begin{tabular}{|c|c|c|c|c|c|c|c|c|}
\hline & No & One & Two & Three & $\begin{array}{l}\text { Above } \\
\text { Three }\end{array}$ & F value & $P$ value & Duncan \\
\hline Value & 4.31 & 4.08 & 4.03 & 4.24 & 3.86 & .891 & .471 & Not significant \\
\hline Brand & 4.22 & 3.93 & 3.86 & 4,08 & 3.57 & 1.304 & .271 & Not significant \\
\hline Relationship & 4.37 & 4.14 & 4.08 & 4.55 & 4.95 & 1.082 & .368 & Not significant \\
\hline Satisfaction & 4.06 & 3.90 & 3.84 & 4.23 & 3.86 & .878 & .479 & Not significant \\
\hline
\end{tabular}

Vehicle Type

Vehicle type to customers on the Part A $\sim \mathrm{E}$ for ANOVA analysis, the results as shown in Table 6 , did not reach significant level, indicating Vehicle type among the various dimensions have no significant effect.

TABLE 6. Vehicle Type On the Differences Between the VARIOUS Dimensions

\begin{tabular}{|c|c|c|c|c|c|c|c|c|}
\hline & Sedan & Sport & Van & $\begin{array}{l}\text { Light } \\
\text { truck }\end{array}$ & $\begin{array}{c}\text { Heavy } \\
\text { truck }\end{array}$ & F value & $\mathrm{P}$ value & Duncan \\
\hline Value & 4.52 & 3.98 & 4.16 & 4.20 & 4.14 & 1.011 & .404 & Not significant \\
\hline Brand & 4.33 & 3.77 & 4.07 & 4.06 & 3.97 & 1.584 & .182 & Not significant \\
\hline Relationship & 4.40 & 3.97 & 4.34 & 4.19 & 4.63 & 1.635 & .169 & Not significant \\
\hline Satisfaction & 4.14 & 3.75 & 4.11 & 3.97 & 4.04 & 1.435 & .225 & Not significant \\
\hline
\end{tabular}




\section{Cylinder Capacity}

Cylinder capacity to customers on the Part A $\sim \mathrm{E}$ for ANOVA analysis, the results as shown in Table 7 , did not reach significant level, indicating Cylinder capacity among the various dimensions have no significant effect.

TABLE 7. CYLINDER CAPACITY OF THE DiFFERENCES BETWEEN THE VARIOUS DiMENSIONS

\begin{tabular}{|c|c|c|c|c|c|c|c|c|}
\hline & $30 \mathrm{~L}$ & $40 \mathrm{~L}$ & $50 \mathrm{~L}$ & $60 \mathrm{~L}$ & $\begin{array}{c}\text { Above } \\
60 \mathrm{~L}\end{array}$ & F Value & P Value & Duncan \\
\hline Value & 4.44 & 3.95 & 4.10 & 4.13 & 4.14 & .993 & .414 & Not significant \\
\hline Brand & 4.33 & 3.67 & 4.03 & 3.93 & 4.05 & 2.079 & .087 & Not significant \\
\hline Relationship & 4.63 & 3.85 & 4.21 & 4.35 & 4.33 & 1.790 & .134 & Not significant \\
\hline Satisfaction & 4.10 & 3.76 & 3.95 & 4.06 & 3.95 & .622 & .647 & Not significant \\
\hline
\end{tabular}

\section{Occupation}

Occupation of the customer-Part A $\sim \mathrm{E}$ for ANOVA

significant level, indicating Occupation between the various analysis, the results as shown in Table 8, did not reach

TABLE 8. OCCUPATION OF THE DIFFERENCES BETWEEN THE VARIOUS DiMENSIONS

\begin{tabular}{c|c|c|c|c|c}
\hline & Agriculture & Industry & Government & Businessman & $\begin{array}{c}\text { Non- } \\
\text { employed }\end{array}$ \\
\hline Value & 4.35 & 4.04 & 4.09 & 4.07 & 4.10 \\
\hline Brand & 4.09 & 3.87 & 3.89 & 4.20 & 3.95 \\
\hline Relationship & 4.33 & 4.06 & 4.25 & 4.40 & 4.26 \\
\hline Satisfaction & 3.42 & 3.85 & 4.08 & Duncan \\
\hline Value & .614 & .653 & & Not significant \\
\hline Brand & .774 & .544 & .700 & Not significant & Not significant \\
\hline Relationship & .549 & .464 & \multicolumn{3}{|c}{ Not significant } \\
\hline Satisfaction & .904 & \multicolumn{3}{|c}{} \\
\hline
\end{tabular}

\section{Annual Income}

Annual income of the customer on the Part $\mathrm{A} \sim \mathrm{E}$ for ANOVA analysis, the results as shown in Table 9, did not reach significant level, indicating Annual income between the various dimensions have no significant effect.

TABLE 9. ANNUAL INCOME OF THE DIFFERENCES BETWEEN THE VARIOUS DIMENSIONS

\begin{tabular}{|c|c|c|c|c|c|}
\hline & $1000-1200$ USD & $1200-2000$ USD & $2000-2500$ USD & $2500-3000$ USD & Above 3000 USD \\
\hline Value & 3.79 & 4.33 & 4.16 & 4.10 & 3.96 \\
\hline Brand & 3.65 & 4.28 & 3.98 & 3.90 & 3.76 \\
\hline Relationship & 4.02 & 4.44 & 4.26 & 4.14 & 3.96 \\
\hline Satisfaction & 3.84 & 4.21 & 3.95 & 3.79 & 4.00 \\
\hline & F value & $\mathrm{P}$ value & & Duncan & \\
\hline Value & 1.855 & .122 & & Not significant & \\
\hline Brand & 2.295 & .062 & & Not significant & \\
\hline Relationship & .824 & .512 & & Not significant & \\
\hline Satisfaction & 1.038 & .390 & & Not significant & \\
\hline
\end{tabular}




\section{Frequent Buying Location}

Location of the customer-Part A $\sim$ E for ANOVA analysis, the results as shown in Table 10, did not reach significant level, showing Frequent Buying Location of the structure had no significant impact on surface.

TABLE 10. LOCATION OF THE DIFFERENCES BETWEEN THE VARIOUS DIMENSIONS (DiSTRICTS)

\begin{tabular}{|c|c|c|c|c|c|}
\hline & Songino/D. & Khan-Uul/ & Chingeltei & Sukh. & Bayanzurkh. \\
\hline Value & 4.42 & 3.95 & 4.10 & 4.12 & 4.08 \\
\hline Brand & 4.26 & 3.73 & 3.93 & 4.08 & 3.84 \\
\hline Relationship & 4.41 & 4.01 & 4.14 & 4.32 & 4.28 \\
\hline \multirow[t]{2}{*}{ Satisfaction } & 4.28 & 3.69 & 3.96 & 4.02 & 3.90 \\
\hline & F value & $\mathrm{P}$ value & & Duncan & \\
\hline Value & .999 & .410 & & Not significant & \\
\hline Brand & 1.441 & .224 & & Not significant & \\
\hline Relationship & .590 & .671 & & Not significant & \\
\hline Satisfaction & 1.244 & .295 & & Not significant & \\
\hline
\end{tabular}

Correlation Analysis. This study used Pearson correlation analysis to verify the correlation between dimensions. The correlation coefficient between variables are positively established, as $\mathrm{p}<.001$, to illustrate the point.

TABLE 11. PEARSon CorRelation COEFFiCIENT TABLE

\begin{tabular}{ccclc}
\hline & Value & Brand & Relationship & Satisfaction \\
\hline Value & 1.000 & & & \\
\hline Brand & $.840 * * *$ & 1.000 & & \\
\hline Relationship & $.753 * * *$ & $.792 * * *$ & 1.000 & 1.000 \\
\hline Satisfaction & $.706 * * *$ & $.699 * * *$ & $.700 * * *$ & \\
\hline
\end{tabular}

Note: $* * * \mathrm{P}<.001$ highly significant correlation

Regression Analysis.

In this study, the dimensions and variables to regression analysis to explore the impact of between dimensions: value, brand, and relationship equities to satisfaction, and to verify whether the hypothesis of this study was established, it is the empirical results are as follows:

TABLE 12. BRAND, VALUE, RELATIONSHIP EQUitiES TO SATISFACTION OF THE REGRESSION ANALYSIS

\begin{tabular}{|c|c|c|c|c|c|c|}
\hline \multicolumn{7}{|c|}{ Satisfaction } \\
\hline & $\mathrm{R}^{2}$ & $\Delta R^{2}$ & FTest & $P$ value & $\begin{array}{l}\text { Standardized } \\
\text { coefficient } \\
\beta \text { distribution }\end{array}$ & Durbin-Watson \\
\hline Value & .499 & .495 & 143.379 & .000 & .706 & 2.290 \\
\hline \multirow{2}{*}{$\begin{array}{r}\text { Brand } \\
\text { Relationship }\end{array}$} & .488 & .485 & 137.345 & .000 & .699 & 2.283 \\
\hline & .495 & .487 & 138.677 & .000 & .700 & 2.067 \\
\hline
\end{tabular}

It can be seen from Table 12, that the regression analysis of the $F$ values and $p$ values reached a to significant level; Durbin-Watson values located within a reasonable range that errors exist between the non-self-related.

\section{Discussions AND IMPLICATIONS}

This research proposed and tested a model of relationships through customer relationship management activities, involving four constructs: value equity, brand equity, 
relationship equity, and satisfaction. Overall, we found that all three independent variables have a direct and significant influence on customer satisfaction.

The results of the research work suggest that the limited budget of marketing activities should be spent on optimal actions and programs to increase or maintain value, brand, and relationship equity.

First, value equity impacts the customer satisfaction. Our finding that value equity is of primary importance in establishing future sales suggests that a firm must meet the expectation of the customers which can be seen as an objective assessment of the utility the firm's products and services offer. It is a customer's balancing of what is given up (price) and what is received in return (satisfaction). Our case company should focus on offering the customers various aspects of value including quality service, quality product, price, and convenience. In doing this way, managers have to be aware that, treating all customers similarly, has the potential to misrepresent the relationship between value equity and satisfaction.

According to the study the brand equity impacts the customer satisfaction. When a brand is perceived as attractive and unique, customers feel less likely to switch to another brand. Subsequently, managers have to consider on building brand equity in order to establish customer satisfaction. In order to ensure that managers focus on building brand awareness, improving brand image and assuring consistency of delivery of brand's promise at a level above the customers' expectations. Our study results revealed the relationship between value and gender. Thus, managers have to avoid the practice of introducing price promotions with the goal of achieving short-term financial gains. Because, it could cause the value of the brand to decrease.

Finally, the relationship equity impacts positively on customer satisfaction. Hopefully, it suggests that the firm has to foster relationship equity by maintaining relationship with customers that will help customers stick to the firm. In order to develop relationship equity, our case company has to consider setting up initiatives such as community activities, loyalty programs that provide "aspirational values," and establishing learning relationships with customers. Relationship equity relates purely to how a firm makes customers feel. A firm could motivate customers to build a community, which rest upon a structured set of relationships among "fans" of a brand. They should also ensure that members of loyalty programs who are engaged in the brand's community, are more loyal than those who are not offered this relationship benefit. Due to the post-transition period from centralized economy into the free market, the Mongolian business environment and culture have not yet shaped as to employ theories of developed free markets.

We have following limitations in our study: (1) Due to the difference of consuming behavior in Mongolia from the western shaped markets' behavior, we tested the simple model of customer equity; (2) According to the dimensions of the customer classifications this research was covered customers in city.

\section{ACKNOWLEDGEMENT}

It is my pleasure to express my extraordinary gratitude to Asia University for allowing and providing me the great opportunity to do this research work. Respectfully, I want to thank my faculty members who co-operated in this study. Basing on the research results we evaluate that our research work contributed in understanding Mongolian consuming behaviour and its aspects. We do hope it will help further researchers to understand the northeast Asian market aspects. Finally, the author wants to thank the case company Petrovis, who is a team team member of this study, and who allowed us to conduct our research work through its own distribution network very successfully.

\section{REFERENCES}

[1] A. G. Woodside a, Martin G. Walser. Building strong brands in retailing. 2006.

[2] R. N. Bolton, K. N. Lemon, and P. C. Verhoef. The Theoretical Underpinnings of Customer Asset Management: A Framework and Propositions for Future Research. Journal of the Academy of Marketing Science. 2004, 32 (3): 271-92.

[3] D. W. Kristof, G. Odekerken-Schröder, and D. Iacobucci. (), Investments in Consumer Relationships: A Cross-Country and Cross-Industry Exploration. Journal of Marketing. 2001, 65 (4): 33-50.

[4] Grewal, Druv, M. Levy, and D. R. Lehmann. Retail Branding and Customer Loyalty: An Overview. Journal of Retailing. 2004, 80 (4): 249-52.

[5] Gounaris, Spiros and V. Stathakopoulos. Antecedents and Consequences of Brand Loyalty: An Empirical Study. Journal of Brand Management. 2004, 11 (4): 283-306.

[6] H. Walker, L. Jean and J. I. Coppett. Building Bridges: The Company Customer Relationship, Journal of Business-to-Business Marketing. 2003, 10 (4): 49-72.

[7] H. Thurau, Thorsten, K. P. Gwinner, and D. Gremler. Understanding Relationship Marketing Outcomes: An Integration of Relational Benefits and Relationship Quality. Journal of Service Research. 2002, 4 (3): 230-47.

[8] K. D. Wutf, G. O. Schroder, D. Lacobucci. Investments in Consumer Relationships: A Cross-Country and Cross-Industry Exploration. 2001.

[9] K. L. Keller. Strategic Brand Management: Building, Measuring and Managing Brand Equity. 2000.

[10] L. N. Katherine, R. T. Rust, and V. A. Zeithaml. What Drives Customer Equity? Marketing Management. 2001, 10 (1): 20-25.

[11] P. Chang, M. Chieng. Building Consumer-Brand Relationship: A Cross-Cultural Experiential View. 2006.

[12] Reinartz, V. Kumar. The Impact of Customer Relationship Characteristics on Profitable Lifetime Duration. Journal of Marketing. 2003, 67 (1): 77-99.

[13] R. T. Rust, V. A. Zeithaml, K. N. Lemon. Driving Customer Equity. 2000.

[14] R. T. Rust, T. S. Chung. Marketing Models of Service and Relationships. 2006.

[15] R. W. Palmatier. Inter firm Relational Drivers of Customer Value. (2008).

[16] R. T. Rust, K. N. Lemon, and V. A. Zeithaml. Return on Marketing: Using Customer Equity to Focus Marketing Strategy. Journal of Marketing. 2004, 68 (1): 109-27.

[17] H. K. Stahl, K. Matzler, and H. Hinterhuber. Linking Customer Lifetime Value with Shareholder Value. Industrial Marketing Management. 2003, 32 (4): 267-79.

[18] Sirdeshmukh, Deepak, J. Singh, and B. Sabol. Consumer Trust, Value, and Loyalty in Relational Exchanges. Journal of Marketing. 2002, 66 (1): $15-37$

[19] Verhoef, C. Peter. Understanding the Effect of Customer Relationship Management Efforts on Customer Retention and Customer Share Development. 2003.

[20] Winer, S. Russell. A Framework for Customer Relationship Management. 2001.

[21] X. Dreze and A. Bonfrer. An Empirical Investigation of the Impact of Communication Timing on Customer Equity. 2008. 
International Journal of Trade, Economics and Finance, Vol. 1, No. 2, August, 2010 2010-023X

[22] Yang, Zhilin and R. T. Peterson. Customer Perceived Value, Satisfaction, and Loyalty: The Role of Switching Costs. Psychology \& Marketing. 2004, 21 (10): 799-822.

[23] Zeithaml, A. Valarie, L. Berry, and A. Parasuraman. The Behavioral Consequences of Service Quality. Journal of Marketing. 1996, 60 (2): 31-46. 